\title{
Article \\ Small Molecule-Peptide Conjugates as Dimerization Inhibitors of Leishmania infantum Trypanothione Disulfide Reductase
}

\author{
Alejandro Revuelto ${ }^{1}{ }^{(}$, Isabel López-Martín ${ }^{1}$, Héctor de Lucio ${ }^{2}{ }^{(\mathbb{D}}$, Juan Carlos García-Soriano ${ }^{2}$, Nicola Zanda ${ }^{1}{ }^{(\mathbb{B}}$, \\ Sonia de Castro ${ }^{1}$, Federico Gago ${ }^{3}\left(\mathbb{D}\right.$, Antonio Jiménez-Ruiz ${ }^{2} \mathbb{D}$, Sonsoles Velázquez ${ }^{1, *(\mathbb{D})}$ \\ and María-José Camarasa ${ }^{1, * \mathbb{D}}$ \\ 1 Instituto de Química Médica (IQM-CSIC), E-28006 Madrid, Spain; alejandro_revu@hotmail.com (A.R.); \\ isabelopezmartin@gmail.com (I.L.-M.); nicoh41@gmail.com (N.Z.); sonia@iqm.csic.es (S.d.C.) \\ 2 Departamento de Biología de Sistemas, Universidad de Alcalá, E-28805 Alcalá de Henares, Spain; \\ hector.lucio@edu.uah.es (H.d.L.); jcarlos.garcias@uah.es (J.C.G.-S.); antonio.jimenez@uah.es (A.J.-R.) \\ 3 Unidad Asociada al IQM-CSIC, Área de Farmacología, Departamento de Ciencias Biomédicas, \\ Universidad de Alcalá, E-28805 Alcalá de Henares, Spain; federico.gago@uah.es \\ * Correspondence: sonsoles@iqm.csic.es (S.V.); mj.camarasa@iqm.csic.es (M.-J.C.); \\ Tel.: +34-912-587-458 (M.-J.C.)
}

check for updates

Citation: Revuelto, A.; López-Martín, I.; de Lucio, H.; García-Soriano, J.C.; Zanda, N.; de Castro, S.; Gago, F.; Jiménez-Ruiz, A.; Velázquez, S.; Camarasa, M.-J. Small

Molecule-Peptide Conjugates as Dimerization Inhibitors of Leishmania infantum Trypanothione Disulfide Reductase. Pharmaceuticals 2021, 14, 689. https://doi.org/10.3390/ ph14070689

Academic Editor: Christophe Dardonville

Received: 21 June 2021

Accepted: 15 July 2021

Published: 17 July 2021

Publisher's Note: MDPI stays neutral with regard to jurisdictional claims in published maps and institutional affiliations.

Copyright: (c) 2021 by the authors. Licensee MDPI, Basel, Switzerland. This article is an open access article distributed under the terms and conditions of the Creative Commons Attribution (CC BY) license (https:/ / creativecommons.org/licenses/by/ $4.0 /)$.

\begin{abstract}
Trypanothione disulfide reductase (TryR) is an essential homodimeric enzyme of trypanosomatid parasites that has been validated as a drug target to fight human infections. Using peptides and peptidomimetics, we previously obtained proof of concept that disrupting protein-protein interactions at the dimer interface of Leishmania infantum TryR (LiTryR) offered an innovative and so far unexploited opportunity for the development of novel antileishmanial agents. Now, we show that linking our previous peptide prototype TRL38 to selected hydrophobic moieties provides a novel series of small-molecule-peptide conjugates that behave as good inhibitors of both LiTryR activity and dimerization.
\end{abstract}

Keywords: leishmaniasis; small molecule-peptide conjugates; dimerization inhibitors; trypanothione disulfide reductase

\section{Introduction}

Leishmaniasis is a vector-borne protozoan infectious disease that affects around 12 million people and falls within the category of neglected tropical diseases [1]. It is one of the leading causes of mortality and morbidity in about 100 countries of mainly tropical and subtropical areas, but also in Mediterranean countries [1-4]. There are more than twenty Leishmania species that cause different forms of leishmaniasis. Among them, L. infantum and L. donovani, which are transmitted through the bite of an infected female sand fly (Phlebotomus), are responsible for visceral leishmaniasis, one of the most severe forms of the disease in human beings that causes 26,000-60,000 deaths each year [1].

Currently, the lack of a vaccine makes the control of leishmaniasis highly dependent on costly drug therapy $[5,6]$. There are a limited number of drugs including pentavalent antimonials, pentamidine, amphotericin B, paromomycin, and miltefosine, all of which can have severe side effects, host toxicity, emergence of resistance, and/or administration problems [7-10]. Therefore, there is a pressing need for the development of more efficient and safer drugs to treat this parasitic disease.

Trypanothione disulfide reductase (TryR), an essential flavoprotein of Leishmania parasites [1,11], is a homodimeric enzyme crucial for antioxidant defense against trypanosomatids, and it is absent in humans. TryR catalyzes the NADPH-dependent reduction of trypanothione disulfide $\left(\mathrm{TS}_{2}\right)$ to the corresponding dithiol $\left(\mathrm{T}[\mathrm{SH}]_{2}\right)[12,13]$. The cellular role of TryR and $\mathrm{T}[\mathrm{SH}]_{2}$ is to maintain intracellular redox equilibrium, in a similar manner to that exerted by the glutathione-glutathione disulfide reductase pair in mammals [14]. TryR is a validated therapeutic target for the discovery of antileishmanial drugs [15-17]. 
The majority of TryR enzyme inhibitors described in the literature interact at the active site where $\mathrm{TS}_{2}$ binds. One of the major disadvantages of this approach is that the binding affinity of these competitive inhibitors must be very high because parasite survival is only compromised when the activity of this enzyme is reduced by more than $90 \%$ [18], which has turned out to be a very elusive goal in vivo. Therefore, noncompetitive, allosteric, or irreversible inhibitors are very attractive, albeit also challenging, alternatives [19-21].

Considering that the biologically functional form of TryR is a homodimer, in 2013, we devised an alternative inhibition strategy aimed at disrupting the protein-protein interactions at the homodimer interface of Leishmania infantum TryR (LiTryR) [22]. Thus, by combining molecular modeling and site-directed mutagenesis studies, we identified and validated, for the first time, Glu436 (located at an interfacial $\alpha$-helix spanning from Pro435 to Met447) as a "hotspot" for LiTryR homodimer stabilization [22]. As a "proof of concept", we designed and tested a small library of linear peptides [22] that were rational variations of the P435-M447 $\alpha$-helix, which includes the dimerization hotspot Glu436. Among them,

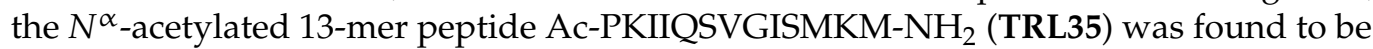
a potent enzyme dimerization disruptor and a strong inhibitor (in the submicromolar range) of the oxidoreductase activity of $L i$ TryR [22]. The C-terminal truncated peptide

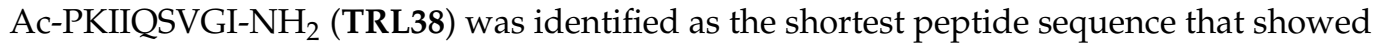
inhibition of LiTryR oxidoreductase activity and also the ability to disrupt enzyme homodimerization [22]. With a view to optimizing these novel LiTryR inhibitors and developing peptidomimetics with enhanced proteolytic stability, a variety of helix-stabilized cyclic and stapled peptides [23-25], as well as $\alpha, \beta^{3}$-peptide foldamers [26], were prepared thereafter. All these peptides and peptidomimetics required attachment to cell-penetrating peptides to allow their cellular uptake and subsequent killing of the parasites in cell culture $[25,26]$. To overcome the unfavorable drug-like properties of these early prototypes, our efforts were then directed towards the design of small molecules (pyrrolopyrimidine-, imidazole-, and triazole-phenyl-thiazole scaffolds) endowed with high potency and more favorable pharmacokinetic characteristics $[27,28]$. Nonetheless, our interest in peptidebased compounds did not wane because these types of compounds are gaining momentum as innovative therapies against different diseases, including leishmaniasis $[29,30]$, due to their biocompatibility, versatility, low toxicity, and concise synthesis [30,31].

Therefore, as part of our continuing efforts to develop novel peptide-based dimerization disruptors of $L i \operatorname{TryR}$, we tried to improve the binding affinity of our previously reported inhibitory peptides by linking them to selected hydrophobic moieties. For the design of these small molecule-peptide conjugates (SMPCs), first, we characterized the putative binding of the peptide prototype TRL38 to a LiTryR monomer (Figure 1) using computational methods, and then identified adjacent regions that could additionally be targeted. Our results highlighted the existence of two large hydrophobic pockets lined by Phe396, Pro398, and Leu399 located at $\sim 5 \AA$ from the $N$-terminus of the peptide (Figure 1A).

Consequently, we decided to synthesize and test a series of SMPCs of general structure I (Figure 2) in which the bulky nonpolar moieties attached to the N-terminus of TRL38 were meant to interact with hydrophobic regions close to the targeted interfacial $\alpha$-helix by means of selected spacers of different lengths and physico-chemical properties. 


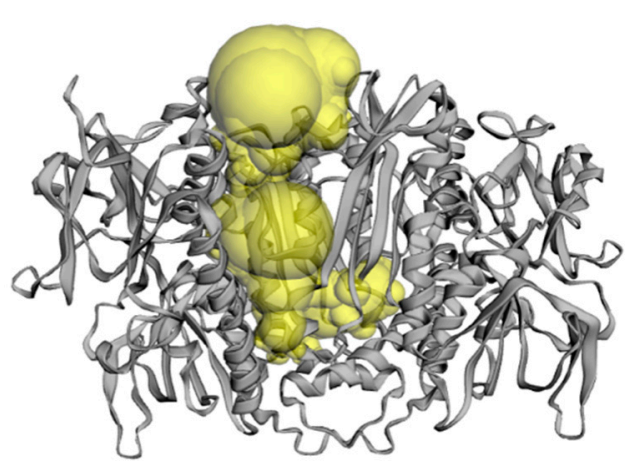

(A)

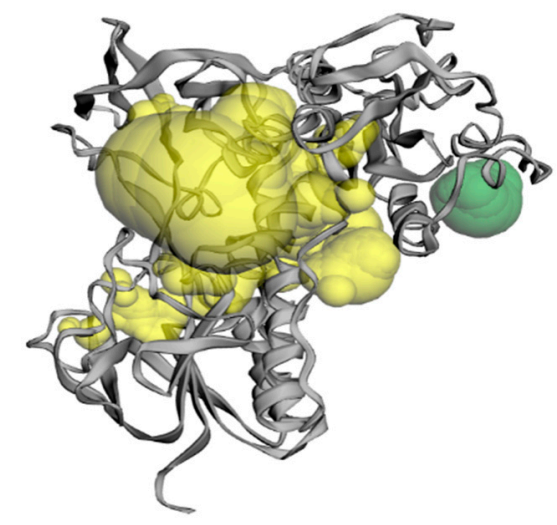

(B)

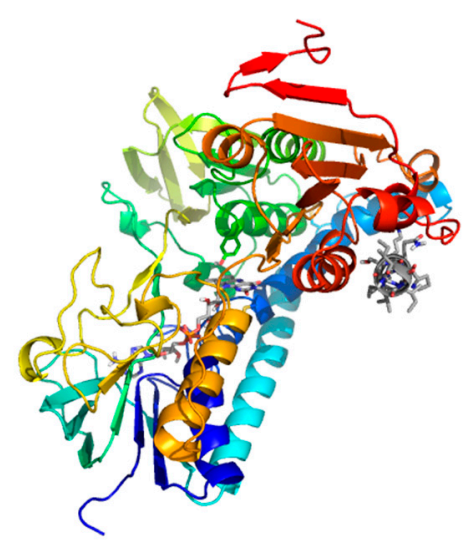

(C)

Figure 1. (A) An illustration of the LiTryR dimer (PDB entry 6I7N [27]) showing the large channel (yellow) connecting the NADPH entry site to the interfacial cavity [28], as calculated by the CASTp web server [32]; (B) an illustration of a LiTryR monomer showing a similar channel (yellow, $2016 \AA^{2}, 2550 \AA^{3}$ ) plus a second one (green, $129 \AA^{2}, 125 \AA^{3}$ ) that makes up the putative target site for the dimer-disrupting peptides and SMPCs; $(\mathbf{C})$ theoretical model of the complex between prototype peptide TRL38 (C atoms in grey) and a LiTryR monomer (rainbow-colored illustration, with $\mathrm{N}$ - and C-termini in blue and red, respectively).

To interact with neighboring hydrophobic regions

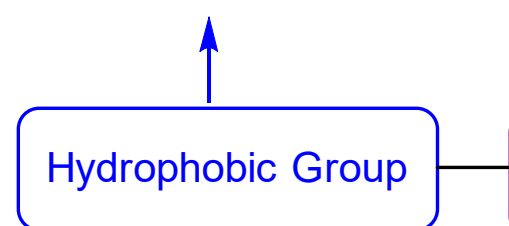

To interact with $\alpha$-helix P435-M447 at the dimerization

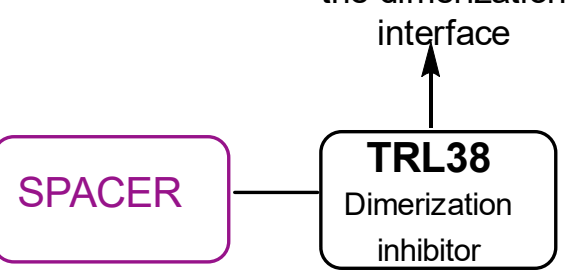

I

Figure 2. General structure of the novel small molecule TRL38 conjugate.

\section{Results}

\subsection{Synthesis}

First, a series of dimerization disruptors containing peptide TRL38 linked to different hydrophobic groups linked to a flexible polyethylene glycol (PEG2) spacer through an amide-type bond (Scheme 1, 1a-g) were prepared based on the premise that the PEG2 linker should improve the water solubility of the final compounds. To study the optimum length of the spacer for activity, a second series of derivatives bearing either a phenyl ring (model compound 2a) or a tricyclic lactam (compound $\mathbf{2 d}$ ) as the hydrophobic substituent bonded to TRL38 through a shorter polyethylene glycol (PEG1) linker were synthesized (compound 1d showed the best biological results in the first series of compounds). Since $\beta$-alanine was also envisaged as a shorter linker, compounds $3 \mathbf{a}$ and $\mathbf{3 d}$, bearing the same substituents as $\mathbf{2} \mathbf{a}$ and $\mathbf{2 d}$, were also prepared. Finally, for comparative purposes, we synthesized compounds $\mathbf{4 a}$ and $\mathbf{4 d}$, in which the hydrophobic groups were directly linked by means of an amide bond to the $N$-terminus of TRL38 (Scheme 1). 


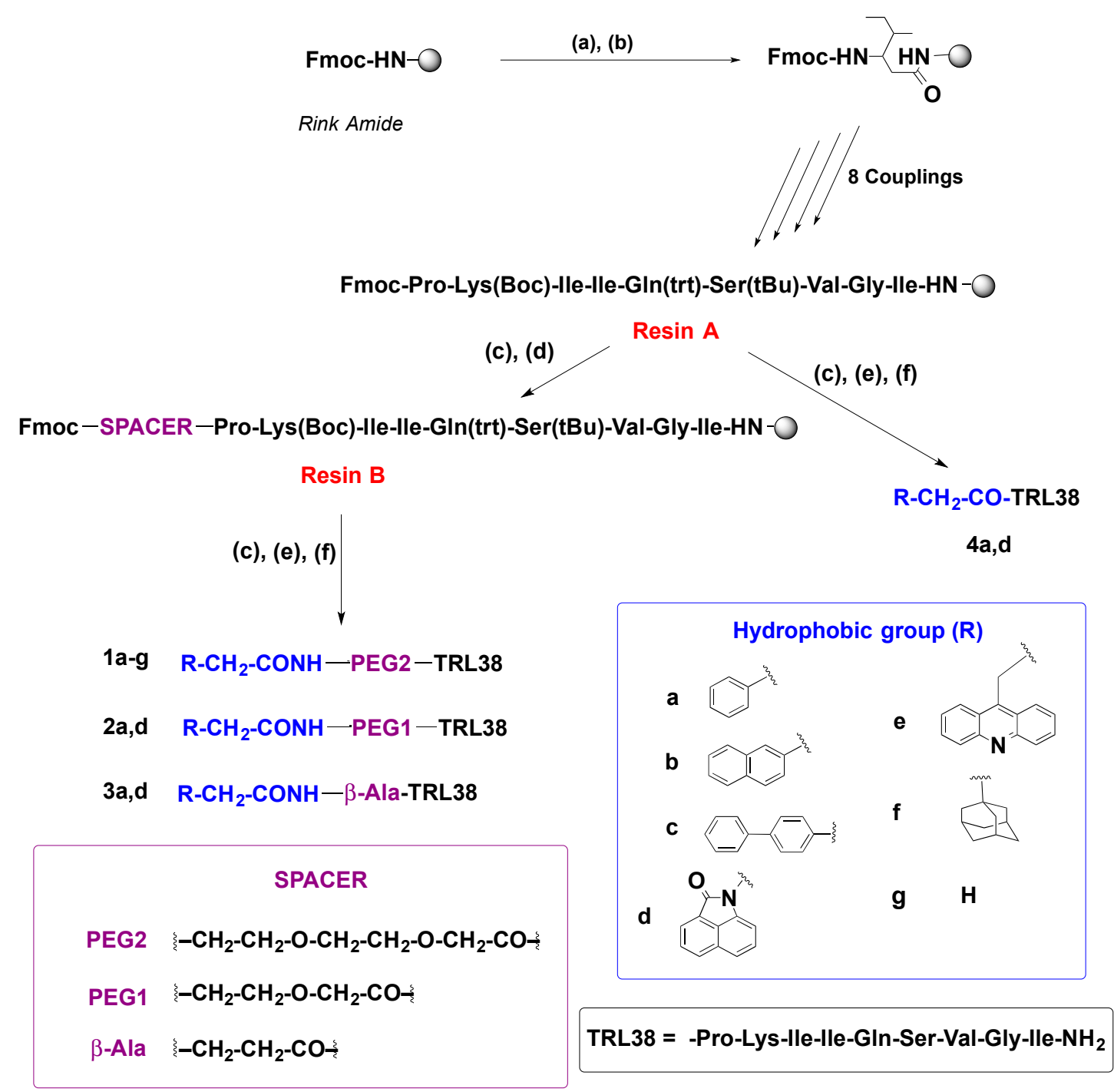

Scheme 1. Solid-phase synthesis of hydrophobic SMPCs $\mathbf{1 a}-\mathbf{g}, \mathbf{2 a}, \mathbf{d}, \mathbf{3 a}, \mathbf{d}$, and $\mathbf{4 a}, \mathbf{d}$ by amide coupling. Reagents and conditions: (a) 20\% Piperidine/DMF; (b) Fmoc-Ile-OH, HCTU, DIPEA, DMF, MW, $40{ }^{\circ} \mathrm{C}, 3 \times 10 \mathrm{~min}$; (c) DBU/piperidine/DMF; (d) Fmoc-SPACER-OH, HCTU, DIPEA, DMF, rt, 2h; (e) $\mathrm{R}_{-} \mathrm{CH}_{2}-\mathrm{COOH}, \mathrm{HCTU}$, DIPEA, DMF, rt, 2 h; (f) TFA, TIPS, and H $2 \mathrm{O}$.

All the SMPCs bearing an amide-bonded substituent were prepared manually following standard solid-phase peptide synthesis (SPPS) protocols using a Rink amide MBHA polystyrene resin and Fmoc/t $\mathrm{Bu}$ chemistry. O-(1H-6-chlorobenzotriazole-1-yl)-1,1,3,3tetramethyluronium hexafluorophosphate (HCTU) [33] was employed as the coupling reagent for peptide elongation, followed by linking of the appropriate spacers to the corresponding $\mathrm{R}^{-} \mathrm{CH}_{2}-\mathrm{COOH}$ acids. The substituted peptides were isolated as carboxamides at the $\mathrm{C}$-terminus.

The synthesis of $\mathbf{1 a -} \mathbf{- g}, \mathbf{2 a}, \mathbf{d}, \mathbf{3 a}, \mathbf{d}$, and $\mathbf{4 a}, \mathbf{d}$ was carried out as follows: After Fmoc deprotection of the resin, under standard piperidine conditions, the first amino acid was introduced in the presence of HCTU as the coupling reagent and DIPEA as the base, at room temperature for $2 \mathrm{~h}$. The coupling of the following amino acids (the side chains of Ser protected with ${ }^{\mathrm{t}} \mathrm{Bu}$, Gln with Trt, or Lys with Boc groups) was carried out under microwave irradiation at $40{ }^{\circ} \mathrm{C}$ in the presence of HCTU/DIPA $(3 \times 10 \mathrm{~min})$. Upon completing elongation, the Fmoc-group of the $\mathrm{N}$-terminus of the peptide (RESIN A) was deprotected, and then the appropriate spacers were coupled (HCTU, DIPEA, DMF room temperature for $2 \mathrm{~h}$ ), followed by Fmoc deprotection and treatment with the corresponding acids (HCTU, DIPEA, and DMF, room temperature for $2 \mathrm{~h}$ ) to give, after final Fmoc deprotection and cleavage (TFA, TIPS, and $\mathrm{H}_{2} \mathrm{O}$ ), the substituted SMPCs $\mathbf{1 a}-\mathbf{g}, \mathbf{2} \mathbf{2}, \mathbf{d}$ and $\mathbf{3 a}, \mathbf{d}$ (Scheme 1). In 
addition, piperidine deprotection of the N-terminal Fmoc-group of RESIN A, followed by coupling with commercially available 2 -oxobenzo $[c d]$ indol- $1(2 H)$-yl acetic acid and 3-(acridin-9-yl)propionic acid, using HCTU as the coupling reagent, gave the final peptide conjugates $4 \mathbf{a}, \mathbf{d}$ (Scheme 1) after deprotection and TFA cleavage from the resin.

We were also interested in synthesizing and testing SMPCs 7 and 8 (Scheme 2), in which the hydrophobic group is bonded to the linker through an aminoalkyl-type bond. These derivatives would allow us to study the influence of the nature of the linkage (amide- vs. aminoalkyl-type) between hydrophobic groups and spacers, and also to obtain positively charged SMPCs (9 and 10, Scheme 2 ) that might eventually give rise to additional interactions with negatively charged amino acids, close to the putative binding site at the LiTryR dimer interface.
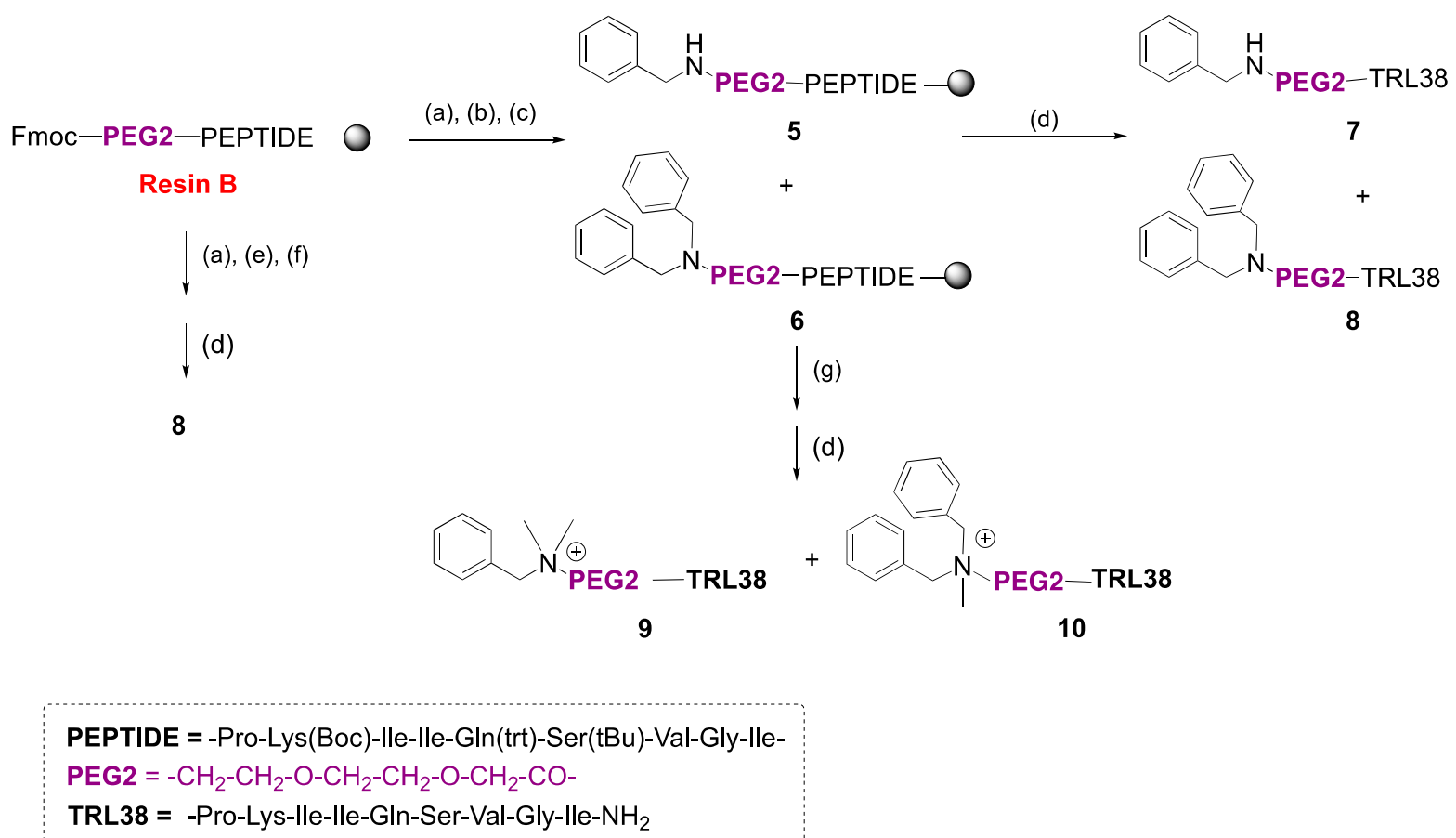

Scheme 2. Solid-phase synthesis of hydrophobic SMPCs 7-10 by reductive amination followed by amine quaternization. Reagents and conditions: (a) DBU, piperidine, DMF; (b) PhCHO (3.6 equivalents); (c) $\mathrm{NaBH}_{3} \mathrm{CN}$ (3.6 equivalents); (d) TFA, TIPS, $\mathrm{H}_{2} \mathrm{O}$; (e) PhCHO (10 equivalents); (f) $\mathrm{NaBH}_{3} \mathrm{CN}$ (10 equivalents); (g) MeI, 2,6-lutidine.

The synthesis of 7 and $\mathbf{8}$ was performed by solid phase reductive amination [34]. Thus, treatment of Fmoc-PEG2-peptidyl RESIN B (Scheme 2) with DBU and piperidine in DMF, followed by reductive amination reaction with 3.6 equivalents of benzaldehyde and $\mathrm{NaCNBH}_{3}$ (3.6 equivalents), afforded, upon cleavage from the resin (TFA, TIPS, $\mathrm{H}_{2} \mathrm{O}$ ), a mixture of mono- and di-aminoalkylated 7 and 8 , in $32 \%$ and $9 \%$ yield, respectively, after purification. However, the disubstituted SMPC 8 was exclusively obtained in $21 \%$ yield when ten equivalents of benzaldehyde and $\mathrm{NaCNBH}_{3}$ were used instead. Finally, treatment of the mixture of $\mathbf{5}$ and $\mathbf{6}$ with MeI and 2,6-lutidine provided the quaternized SMPCs 9 and 10 in $25 \%$ and $8 \%$ yield, respectively, after cleavage and purification. All the compounds synthesized in this work were characterized as trifluoroacetate salts by analytical HPLC and HRMS after purification on a Biotage Isolera or by semi-preparative HPLC.

\subsection{Biological Evaluation}

All the synthesized novel SMPCs were evaluated as LiTryR inhibitors in both the oxidoreductase activity [35] and the dimer quantitation assays [22,35]. The prototype peptide TRL38 was included as the reference compound. The $\mathrm{IC}_{50}$ values obtained for activity $\left(\mathrm{IC}_{50}^{\text {act }}\right)$ and dimerization $\left(\mathrm{IC}_{50}^{\mathrm{dim}}\right)$ are shown in Table 1. 
Table 1. Half-maximal inhibitory concentration $\left(\mathrm{IC}_{50}\right) \pm$ standard error (SE) values for TRL38 conjugates in the $L i T r y R$ oxidoreductase activity and dimer quantitation assays ${ }^{a}$.

\begin{tabular}{|c|c|c|c|c|}
\hline Peptide & $\mathbf{R}$ & Spacer Type & $\mathrm{IC}_{50}^{\mathrm{act}}(\mu \mathrm{M})^{\mathrm{c}}$ & $I C_{50}^{\operatorname{dim}}(\mu \mathrm{M}){ }^{d}$ \\
\hline TRL38 $^{b}$ & & & $\begin{array}{c}>25 \\
(65.1 \%)^{\mathrm{e}, *}\end{array}$ & $\begin{array}{c}>25 \\
(61.4 \%)^{e, \&}\end{array}$ \\
\hline \multicolumn{5}{|c|}{ Amide Link } \\
\hline $1 \mathrm{a}$ & & $-\mathrm{CH}_{2}-\mathrm{CH}_{2}-\mathrm{O}-\mathrm{CH}_{2}-\mathrm{CH}_{2}-\mathrm{O}-\mathrm{CH}_{2}-\mathrm{CO}-$ & $22.0 \pm 0.7$ & $9.4 \pm 0.1$ \\
\hline $1 b$ & & $-\mathrm{CH}_{2}-\mathrm{CH}_{2}-\mathrm{O}-\mathrm{CH}_{2}-\mathrm{CH}_{2}-\mathrm{O}-\mathrm{CH}_{2}-\mathrm{CO}-$ & $18.2 \pm 1.0$ & $8.7 \pm 0.5$ \\
\hline 1c & & $-\mathrm{CH}_{2}-\mathrm{CH}_{2}-\mathrm{O}-\mathrm{CH}_{2}-\mathrm{CH}_{2}-\mathrm{O}-\mathrm{CH}_{2}-\mathrm{CO}-$ & $16.6 \pm 3.8$ & $22.9 \pm 1.4$ \\
\hline $1 d$ & & $-\mathrm{CH}_{2}-\mathrm{CH}_{2}-\mathrm{O}-\mathrm{CH}_{2}-\mathrm{CH}_{2}-\mathrm{O}-\mathrm{CH}_{2}-\mathrm{CO}-$ & $6.7 \pm 0.4$ & $7.8 \pm 0.1$ \\
\hline $1 e$ & & $-\mathrm{CH}_{2}-\mathrm{CH}_{2}-\mathrm{O}-\mathrm{CH}_{2}-\mathrm{CH}_{2}-\mathrm{O}-\mathrm{CH}_{2}-\mathrm{CO}-$ & $14.6 \pm 3.8$ & $5.5 \pm 0.5$ \\
\hline 1f & & $-\mathrm{CH}_{2}-\mathrm{CH}_{2}-\mathrm{O}-\mathrm{CH}_{2}-\mathrm{CH}_{2}-\mathrm{O}-\mathrm{CH}_{2}-\mathrm{CO}-$ & $7.6 \pm 1.2$ & $8.1 \pm 0.2$ \\
\hline $3 g$ & $\mathrm{H}$ & $-\mathrm{CH}_{2}-\mathrm{CH}_{2}-\mathrm{O}-\mathrm{CH}_{2}-\mathrm{CH}_{2}-\mathrm{O}-\mathrm{CH}_{2}-\mathrm{CO}-$ & $13.4 \pm 1.7$ & $21.1 \pm 1.6$ \\
\hline $2 a$ & & $-\mathrm{CH}_{2}-\mathrm{CH}_{2}-\mathrm{O}-\mathrm{CH}_{2}-\mathrm{CO}-$ & $22.3 \pm 1.5$ & $15.0 \pm 0.6$ \\
\hline $2 d$ & & $-\mathrm{CH}_{2}-\mathrm{CH}_{2}-\mathrm{O}-\mathrm{CH}_{2}-\mathrm{CO}-$ & $6.9 \pm 1.9$ & $7.1 \pm 0.1$ \\
\hline $3 a$ & & $-\mathrm{CH}_{2}-\mathrm{CH}_{2}-\mathrm{CO}-$ & $20.6 \pm 1.6$ & $12.7 \pm 1.1$ \\
\hline $3 d$ & & $-\mathrm{CH}_{2}-\mathrm{CH}_{2}-\mathrm{CO}-$ & $10.1 \pm 1.5$ & $5.3 \pm 0.9$ \\
\hline $4 a$ & & No spacer & $10.3 \pm 1.8$ & $11.4 \pm 0.1$ \\
\hline $4 d$ & & No spacer & $8.0 \pm 1.5$ & $7.1 \pm 0.2$ \\
\hline \multicolumn{5}{|c|}{ Aminoalkyl link } \\
\hline 7 & $\mathrm{Ph}-\mathrm{CH}_{2} \mathrm{~N}$ & $-\mathrm{CH}_{2}-\mathrm{CH}_{2}-\mathrm{O}-\mathrm{CH}_{2}-\mathrm{CH}_{2}-\mathrm{O}-\mathrm{CH}_{2}-\mathrm{CO}-$ & $8.3 \pm 1.4$ & $12.6 \pm 0.6$ \\
\hline 8 & $\left(\mathrm{Ph}-\mathrm{CH}_{2}\right)_{2} \mathrm{~N}$ & $-\mathrm{CH}_{2}-\mathrm{CH}_{2}-\mathrm{O}-\mathrm{CH}_{2}-\mathrm{CH}_{2}-\mathrm{O}-\mathrm{CH}_{2}-\mathrm{CO}-$ & $9.8 \pm 2.3$ & $7.1 \pm 0.5$ \\
\hline 9 & $\mathrm{Ph}-\mathrm{CH}_{2} \mathrm{~N}^{+}(\mathrm{Me})_{2}$ & $-\mathrm{CH}_{2}-\mathrm{CH}_{2}-\mathrm{O}-\mathrm{CH}_{2}-\mathrm{CH}_{2}-\mathrm{O}-\mathrm{CH}_{2}-\mathrm{CO}-$ & $18.3 \pm 2.6$ & $>25(53.3 \%) \&$ \\
\hline 10 & $\left(\mathrm{Ph}-\mathrm{CH}_{2}\right)_{2} \mathrm{~N}^{+} \mathrm{Me}$ & $-\mathrm{CH}_{2}-\mathrm{CH}_{2}-\mathrm{O}-\mathrm{CH}_{2}-\mathrm{CH}_{2}-\mathrm{O}-\mathrm{CH}_{2}-\mathrm{CO}-$ & $9.2 \pm 1.1$ & $21.2 \pm 3.5$ \\
\hline
\end{tabular}

${ }^{a}$ Results are representative of three independent experiments, each performed in triplicate. ${ }^{\mathrm{b}}$ Linear peptide TRL38 is included as the reference compound. ${ }^{c}$ Enzymatic activity according to a modified assay described by Hamilton et al. [35]. ${ }^{d}$ Dimer quantitation ELISA [22]. ${ }^{\text {e }}$ Percentage of inhibition observed at $25 \mu \mathrm{M}$ (reliable $\mathrm{IC}_{50}$ values could not be determined in this case). Previously reported $\mathrm{IC}_{50} \mathrm{values}$ were obtained after preincubation of LiTryR with TRL38 for $10 \mathrm{~min}$ [22]. The values shown in this table were obtained without prior incubation due to the observed time dependence of the inhibitory process [36]. ${ }^{*}$ LiTryR oxidoreductase activity at $25 \mu \mathrm{M}(\%)$. \& $L i \operatorname{TryR}$ dimer at $25 \mu \mathrm{M}(\%)$.

\subsection{Molecular Modeling and Computer Simulations}

Characterization of the geometric and topological properties of LiTryR dimer and monomer by means of the CASTp server [32] showed the largest pocket connecting the bulk solvent to the isoalloxazine ring of the FAD cofactor (Figure 1) and delineated the cavity at one monomer that makes up the binding site for the P435-M447 $\alpha$-helix from the other monomer. 
Molecular dynamic simulations of the putative complex formed between a LiTryR monomer and $4 \mathrm{~d}$, taken as a representative linkerless SMPC, showed initial preservation of the $\alpha$-helical conformation of the peptide, but subsequent disruption due to protein disorganization at the interfacial region encompassing G448-S470 and mutual side chain adaptation (Figure 3). This progression is likely responsible for dimer disruption by shifting the monomer-dimer conformational equilibrium towards the monomeric, inactive form. Although the naphtholactam moiety initially stabilized the $\alpha$-helix by means of hydrophobic interactions with the Pro and Ile side chains present at the $\mathrm{N}$-terminus of the peptide (Figure 3A), these contacts were later lost and eventually exchanged with interactions with other residues (Figure 3C). A similar behavior can be expected for $\mathbf{1 d}, \mathbf{2 d}$, and $3 \mathbf{d}$ possessing longer linkers, in view of the experimental finding that the impact of linker length on activity appears to be almost negligible.

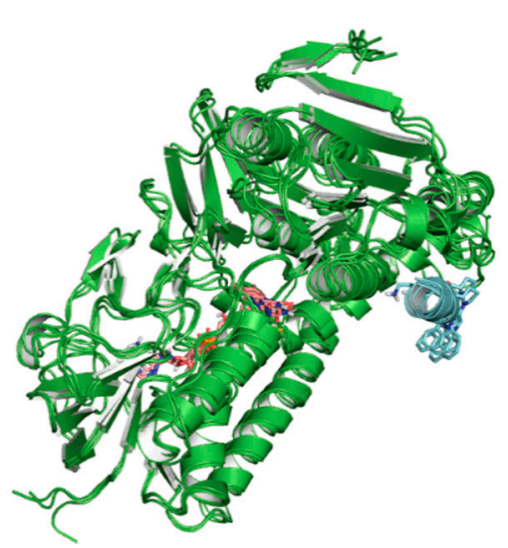

(A)

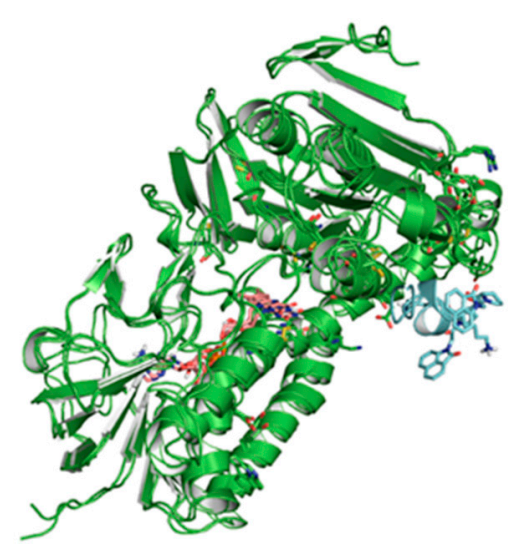

(B)

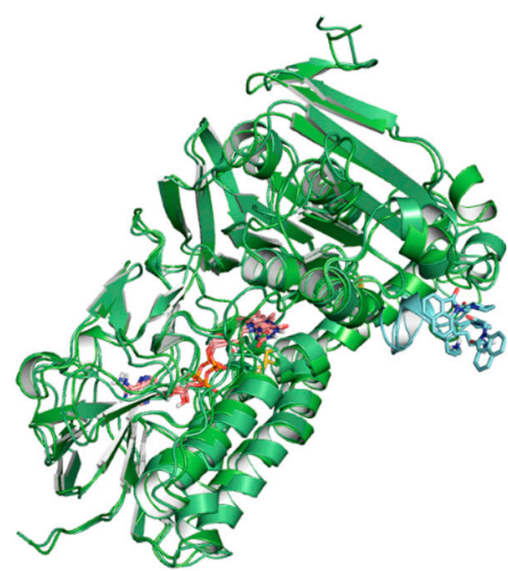

(C)

Figure 3. Time evolution of the simulated complex between LiTryR monomer (C atoms in green) and SMPC 4d (C atoms in cyan). The superimposed snapshots correspond to times 5, 25, and $50 \mathrm{~ns}$ (A), 75 and $100 \mathrm{~ns}$ (B), and 125 and $150 \mathrm{~ns}$ (C) of the unrestrained molecular dynamics trajectory in explicit solvent. The FAD cofactor is displayed as sticks with $\mathrm{C}$ atoms colored in pink.

\section{Discussion}

In general, all the hydrophobic moiety TRL38 conjugates were good inhibitors of both activity and dimerization of the enzyme, showing a significant improvement with respect to the parent TRL38 peptide, regardless of the kind of linkage (i.e., amide- or aminoalkyltype) between the spacer and the hydrophobic group. This enhancement is highly relevant for SMPCs $\mathbf{1 a}, \mathbf{1 d}, \mathbf{1 f}, \mathbf{2 d}, \mathbf{3 d}, \mathbf{4 d}, \mathbf{7}$, and $\mathbf{8}$. The length and nature of the spacer does not appear to have a significant influence on activity/dimerization of the compounds (cf., for example, $\mathbf{1 d}$ vs. $\mathbf{2 d}, \mathbf{3 d}$, or $\mathbf{4 d}$ ), but the nature of the hydrophobic substituent does. Thus, in the amide-type conjugates, and according to the data shown in Table 1 for the first series of SMPCs bearing a PEG2 linker, the best inhibition of activity/dimerization was displayed by those bearing the tricyclic lactam $\left(1 \mathrm{~d}, \mathrm{IC}_{50}^{\text {act }}=6.7 \mu \mathrm{M}\right.$ and $\left.\mathrm{IC}_{50}^{\text {dim }}=7.8 \mu \mathrm{M}\right)$ and the adamantyl (1f, IC $\mathrm{C}_{50}^{\text {act }}=7.6 \mu \mathrm{M}$ and $\left.\mathrm{IC}_{50}^{\text {dim }}=8.1 \mu \mathrm{M}\right)$ substituents. Nonetheless, the increased hydrophobicity of $\mathbf{1 f}$ translated into an undesired decrease in solubility. The acridine-conjugated peptide 1 e was also a good dimerization inhibitor $\left(\mathrm{IC}_{50}^{\mathrm{dim}}=5.5 \mu \mathrm{M}\right)$. The effect of the spacers on LiTryR activity/dimerization was assessed by comparing the SMPCs substituted with either a phenyl (1a, 2a, 3a, and 4a) or the naphtholactam (1d, 2d, 3d, and 4d) and bearing PEG2, PEG1, $\beta$-alanyl, and no spacer, respectively. Compounds containing the naphtholactam moiety turned out to be more potent in both assays than the corresponding phenyl derivatives $\left(\mathrm{IC}_{50}^{\mathrm{act}}=10.1-6.7 \mu \mathrm{M}\right.$ vs. $22.3-10.3 \mu \mathrm{M}$ and $\mathrm{IC}_{50}^{\mathrm{dim}}=7.8-5.3 \mu \mathrm{M}$ vs. $\left.15.0-9.4 \mu \mathrm{M}\right)$, and again the length and nature of the spacer were found to be not crucial for activity. Taken together, these results reinforce the superiority of the amphipathic tricyclic lactam for conjugation to TRL38. 
Regarding SMPCs 7-10, introduction of the aminoalkyl-type linker leads to increased inhibition of the oxidoreductase activity but also to a slight decrease in dimerization disruption (cf. 1a vs. 7). Attachment of a second benzyl group to the nitrogen (8 vs. 7) has greater impact on dimerization (two-fold increase) than that on enzymatic activity. Different effects on dimerization vs. enzymatic activity have been previously reported to be a consequence of the slow kinetics that have been observed to characterize dimer disruption [36]. Finally, a positive charge at the $\mathrm{N}$ is detrimental for dimerization (cf. 7 vs. 9 , and 8 vs. 10) while the impact on oxidoreductase activity is either lower or nil.

Taken together, our data show that all the hydrophobic SMPCs obtained display significantly improved inhibition of LiTryR dimerization and enzymatic activity over the parent TRL38 peptide prototype. It became apparent that the nature of the hydrophobic group attached to the peptide prototype TRL38 has a much greater impact on potency than the nature and length of the spacers. Consequently, the SMPCs bearing a naphtholactam $(\mathbf{1 d}, \mathbf{2 d}, \mathbf{3 d}$, or $\mathbf{4 d}$ ) appear to be the best candidates for further studies in the search for novel agents against leishmaniasis.

\section{Materials and Methods}

\subsection{Instrumentation and Chemicals}

Unless otherwise specified, analytical grade solvents and commercially available reagents were used without further purification. Water sensitive reactions were carried out under argon atmosphere. HCTU, DIPEA, $\mathrm{Ac}_{2} \mathrm{O}$, and protected spacers were purchased from Sigma-Aldrich (Darmstadt, Germany), protected bulky acids were purchased from Fluorochem (Glossop, United Kingdom), and TFA was purchased from Fluka (Germany). Fmoc-protected amino acids were purchased from Fluka, Novabiochem (Merck, Germany), and Iris Biotech (Marktredwitz, Germany). Fmoc-protected Rink amide MBHA resin (0.71 mmol/g loading) was purchased from GS Biochem (China). All amino acids used were of the L configuration.

Target peptides were synthesized using the standard Fmoc/tBu solid-phase orthogonal protection strategy. Compounds were synthesized manually on a 20-position vacuum manifold (Omega, Bienne, Switzerland) connected to a vacuum pump using $20 \mathrm{~mL}$ polypropylene syringes (Dubelcco) with a preinserted frit and a teflon stopcock to do the washings and remove the solvents and excess reagents. The coupling reactions were carried out on solid phase using microwave radiation in a Biotage Initiator reactor (Uppsala, Sweden) in a $5 \mathrm{~mL}$ vial. Excluding coupling reactions on the microwave reactor, the remaining SPPS reactions were performed, over the previously swollen resin (MBHA polystyrene resin), inside the syringes by adding the corresponding reagents and subsequent automatic stirring on a Grant Bio (POS-300) orbital shaker. After cleavage, the acidic crudes were sedimented in $\mathrm{Et}_{2} \mathrm{O}$ on a Hettlich Universal 320R centrifuge (Sigma-Aldrich ) at $5000 \mathrm{rpm}$. All the crude and samples were lyophilized using water/acetonitrile mixtures on a Telstar 6-80 instrument. The monitoring of the reactions and final compounds was also performed by HPLC/MS on a HPLC-Waters 12695 connected to a Waters Micromass ZQ spectrometer. The SMPCs were purified by HPFC (high performance flash chromatography) on an SP1 Isolera Biotage instrument using reverse-phase columns (KP-C18-HS $12 \mathrm{~g}$ ) or on a semipreparative HPLC Waters equipment. As mobile phase, mixtures of A/B were used, where $\mathrm{A}=0.05 \%$ TFA water and $\mathrm{B}=$ acetonitrile with a flow rate of $7 \mathrm{~mL} / \mathrm{min}$, using a gradient from $0 \%$ of $B$ to $100 \%$ of $B$ in 30-45 min and were detected at $217 \mathrm{~nm}$. After purification, SMPCs were lyophilized and dried under reduced pressure in the presence of $\mathrm{P}_{2} \mathrm{O}_{5}$.

The purity of the final SMPCs was checked by an analytical RP-HPLC system on an Agilent Infinity instrument equipped with a diode array and a C18 Sunfire column $(4.6 \times 150 \mathrm{~mm}$, $3.5 \mu \mathrm{m})$. As mobile phase, mixtures of $\mathrm{A} / \mathrm{B}$ were used, where $\mathrm{A}=0.05 \%$ TFA water and $\mathrm{B}$ $=$ acetonitrile with a flow rate of $1 \mathrm{~mL} / \mathrm{min}$. The peptides were analyzed at $214 \mathrm{~nm}$ and at $254 \mathrm{~nm}$ in a gradient from $2 \%$ of B to $100 \%$ of B in $15 \mathrm{~min}$. HRMS (EI+) was carried out in an 
Agilent 6520 Accurate-Mass Q-TOF LC/MS mass spectrometer (Voyager DE-STR Applied Biosystems) using $1 \%$ formic acid methanol or methanol/acetonitrile mixtures.

\subsection{Syntheses}

\subsubsection{General Synthetic Protocols}

The general peptide elongation procedure involved the following: Fmoc-protected Rink amide MBHA resin was swollen in DCM/DMF/DCM/DMF $(3 \times 0.5 \mathrm{~min})$, in a filter-equipped syringe. Then, Fmoc removal was performed by treating the resin with a mixture of piperidine/DBU/DMF (1:1:48 in volume) at room temperature $(1 \times 1 \mathrm{~min}$ and $3 \times 10 \mathrm{~min})$ and washed with DMF/DCM/DMF/DCM $(3 \times 0.5 \mathrm{~min}$, each solvent). Later, the free $\mathrm{N} \alpha$-terminal swollen resin (1 equivalent) was transferred to a $5 \mathrm{~mL}$ microwave pressure flask and a solution of the corresponding Fmoc-AA-OH (1.2 equivalents), HCTU (1.2 equivalents), and DIPEA (2.4 equivalents), suspended in dry DMF, were added. The vial was sealed, and the reaction was heated in a microwave vial equipped with a magnetic stirrer, for $10 \mathrm{~min}$ at $40^{\circ} \mathrm{C}$. Then, the vial was opened, the supernatant was removed, and new coupling mixture was added. This process was repeated 3 times in total $(3 \times 10 \mathrm{~min})$ until complete coupling. After the reaction was complete, the resin was transferred to a fritted syringe, drained, washed extensively with (DMF/DCM/DMF/DCM, $5 \times 0.5 \mathrm{~min})$, and dried under vacuum. This protocol was repeated for the sequential anchoring of each amino acid until sequence completion. Coupling reactions to primary amines were monitored by the Kaiser ninhydrin test, and to secondary amines by a more sensitive Choranil test. Half-way through the growing sequence, the progress of the reaction was followed by the HPLC-MS analysis of a small sample of peptidyl resin after acidic cleavage.

The general procedure for coupling the spacer and the hydrophobic group to the N-terminus of TRL38 involved the following: Following a similar procedure to that described for peptide elongation, introduction of both spacers and the final hydrophobic residues was performed by SPPS. The peptidyl resin was swollen $(3 \times 10 \mathrm{~mL}$ each solvent, $\mathrm{DCM} / \mathrm{DMF} / \mathrm{DCM} / \mathrm{DMF}$ ) in a filter-equipped syringe. Next, the Fmoc protecting group was removed (piperidine/DBU/DMF, 1:1:48 in volume) at room temperature $(1 \times 1 \mathrm{~min}$ and $3 \times 10 \mathrm{~min})$ and washed with DMF/DCM/DMF/DCM $(3 \times 0.5 \mathrm{~min}$, each solvent). Then, the resin was swollen again and treated with the appropriate Fmoc-NH-spacer acid (2 equivalents) or Fmoc-NH-hydrophobic-COOH (2 equivalents) in the presence of HCTU (2 equivalents) and of DIPEA (4 equivalents) in dry DMF (4-5 mL) and were reacted under automatic stirring on a Grant Bio (POS-300) orbital shaker at $320 \mathrm{rpm}$ at room temperature for $2 \mathrm{~h}$. Then, the syringe was attached to the manifold and the excess of reaction mixture was removed by filtration under vacuum. Finally, the resin was washed three times with each solvent and dried under vacuum for $10 \mathrm{~min}$.

After the incorporation of the spacer, and following a similar strategy, the hydrophobic groups at the N-terminus were introduced using the corresponding Fmoc-NH-hydrophobic$\mathrm{COOH}$ (2 equivalents) in each case.

The general procedure for reductive amination involved the following: Peptidyl resin was swollen $(3 \times 10 \mathrm{~mL}$ each solvent, DCM/DMF/DCM/DMF). Then, the Fmoc group was removed upon treating with a solution of DBU/piperidine/DMF, 1:1:48 v:v:v $(1 \times 1 \mathrm{~min}$ and $3 \times 10 \mathrm{~min})$. After washing with DCM and DMF twice under vacuum $(2 \times 0.5 \mathrm{~min})$, the peptidyl resin was transferred to a $10 \mathrm{~mL}$ round bottom flask and suspended in $2 \mathrm{~mL}$ of anhydrous THF. The flask was sealed with a septum, and then a solution of benzaldehyde (3.6-10 equivalents) in a 1:1 mixture of $\mathrm{H}_{2} \mathrm{O} / \mathrm{AcOH}(0.15 \mathrm{~mL})$ was added; the reaction mixture was stirred in the orbital shaker for $1 \mathrm{~h}$ at $400 \mathrm{rpm}$. Next, 3.6-10 equivalents of $\mathrm{NaBH}_{3} \mathrm{CN}$ were added and the reaction was stirred (orbital shaking) for $3 \mathrm{~h}$ at room temperature. Finally, the reaction mixture was transferred back to a syringe, washed three times with DCM and DMF and dried under vacuum for $10 \mathrm{~min}$.

The procedure for the amine quaternization reaction involved the following: Fmocprotected swollen resin, placed in a sealed round bottom flask, was treated with an excess of MeI (10 equivalents) and 2,6-lutidine (10 equivalents), the flask was sealed with a septum, 
and the mixture was shaken overnight at room temperature at $400 \mathrm{rpm}$. The suspension was filtered in a fritted syringe in the manifold, washed several times with DCM and DMF, and finally dried for 10 min under vacuum.

The general cleavage procedure involved the following: The well-dried functionalized resin-bonded derivatives ( 1 volume) in a fritted syringe were treated with TFA/TIPS/ $\mathrm{H}_{2} \mathrm{O}$ 95:2.5:2.5 (5 volumes) for $4 \mathrm{~h}$ at room temperature under $320 \mathrm{rpm}$ orbital shaking. Then, the filtrates were precipitated over cold $\mathrm{Et}_{2} \mathrm{O}$, in a $50 \mathrm{~mL}$ Falcon tube, and centrifuged at $5000 \mathrm{rpm}$ for $10 \mathrm{~min}$ at $-15^{\circ} \mathrm{C}$. The supernatant was removed, and the process was repeated three times. After supernatant removal, the pellet was suspended in a mixture of water/acetonitrile and freeze-dried. The crudes were purified to give the target SMPCs in high purity.

\subsubsection{Solid-Phase Synthesis of Peptide Conjugates $1 \mathbf{a}-\mathbf{g}, \mathbf{2 a}, \mathbf{d}, 3 \mathbf{a}, \mathbf{d}, 4 \mathbf{a}, \mathbf{d}$, and $\mathbf{7 - 1 0}$}

The solid-phase syntheses of the peptide conjugates were as follows:

Ph- $\mathrm{CH}_{2}-\mathrm{CO}-\mathrm{NH}-\left(\mathrm{CH}_{2}\right)_{2}-\mathrm{O}-\left(\mathrm{CH}_{2}\right)_{2}-\mathrm{O}-\mathrm{CH}_{2}-\mathrm{CO}-\mathrm{NH}-\mathrm{PKIIQSVGI-NH} \mathrm{H}_{2}$ (1a): The general protocol for elongation was followed with $0.28 \mathrm{mmol}$ of resin to give Fmoc-peptidyl resin. Next, Fmoc removal from peptidyl resin $(0.11 \mathrm{mmol})$ followed by subsequent Fmoc-PEG2-OH and phenylacetic acid couplings were performed. After cleavage, the crude was purified by reverse-phase chromatography on a Biotage Isolera to give 1a (156.0 mg, 39\% overall yield) as a white lyophilized cotton-like solid. Analytical HPLC (gradient 10-100\% of acetonitrile in $10 \mathrm{~min})$, retention time $=6.13 \mathrm{~min}(99 \%$ analytical purity). HRMS $(\mathrm{ESI},+)$ $\mathrm{m} / \mathrm{z}$ was calculated for $\mathrm{C}_{58} \mathrm{H}_{97} \mathrm{~N}_{13} \mathrm{O}_{15} 1215.72$ and found 1215.73 (3.94 ppm).

Naphthyl-CH $\mathrm{C}_{2}-\mathrm{CO}-\mathrm{NH}-\left(\mathrm{CH}_{2}\right)_{2}-\mathrm{O}-\left(\mathrm{CH}_{2}\right)_{2}-\mathrm{O}-\mathrm{CH}_{2}-\mathrm{CO}-\mathrm{NH}-\mathrm{PKIIQSVGI-NH} \mathrm{H}_{2}$ (1b): From $0.07 \mathrm{mmol}$ of resin and after elongation, Fmoc-PEG2-OH and naphthyl acetic acid couplings cleavage and purification $\mathbf{1 b}$ was isolated $(22.4 \mathrm{mg}, 26 \%$ overall yield) as a white lyophilized cotton-like solid. Analytical HPLC (gradient $2-100 \%$ of acetonitrile in $10 \mathrm{~min}$ ), retention time $=7.24 \mathrm{~min}(96 \%$ analytical purity $)$. HRMS $(\mathrm{ESI},+) \mathrm{m} / \mathrm{z}$ was calculated for $\mathrm{C}_{62} \mathrm{H}_{99} \mathrm{~N}_{13} \mathrm{O}_{15} 1266.55$ and found 1265.74 (-0.22 ppm).

Biphenyl- $\mathrm{CH}_{2}-\mathrm{CO}-\mathrm{NH}-\left(\mathrm{CH}_{2}\right)_{2}-\mathrm{O}-\left(\mathrm{CH}_{2}\right)_{2}-\mathrm{O}-\mathrm{CH}_{2}-\mathrm{CO}-\mathrm{NH}-\mathrm{PKIIQSVGI}-\mathrm{NH}_{2}$ (1c): The general protocol was followed with $0.07 \mathrm{mmol}$ of resin, Fmoc-PEG2-OH and biphenyl acetic acid, to give, after purification, 1c (107.7 $\mathrm{mg}, 42 \%$ overall yield) as a white lyophilized cotton-like solid. Analytical HPLC (gradient 2-100\% of acetonitrile in $10 \mathrm{~min}$ ), retention time $=7.17 \mathrm{~min}$ (97\% analytical purity). HRMS (ESI,+) m/z was calculated for $\mathrm{C}_{64} \mathrm{H}_{101} \mathrm{~N}_{13} \mathrm{O}_{15} 1292.59$ and found 1291.75 (3.94 ppm).

(2-(2-oxobenzo[cd]indol-1(2H)-yl)- $\mathrm{CH}_{2}-\mathrm{CO}-\mathrm{NH}-\left(\mathrm{CH}_{2}\right)_{2}-\mathrm{O}-\left(\mathrm{CH}_{2}\right)_{2}-\mathrm{O}-\mathrm{CH}_{2}-\mathrm{CO}-\mathrm{NH}-\mathrm{PKIIQS}$ $\mathrm{VGI}_{-\mathrm{NH}_{2}}$ (1d): The general protocol was followed with $0.07 \mathrm{mmol}$ of resin, Fmoc-PEG2$\mathrm{OH}$, and 2-(2-oxobenzo[cd]indol-1(2H)-yl)acetic acid, to afford, after purification, 1d as a white lyophilized cotton-like solid ( $24.7 \mathrm{mg}$, 32\% overall yield). Analytical HPLC (gradient $10-100 \%$ of acetonitrile in $10 \mathrm{~min})$, retention time $=6.32 \mathrm{~min}$ ( $98 \%$ analytical purity). HRMS $(\mathrm{ESI},+) \mathrm{m} / \mathrm{z}$ was calculated for $\mathrm{C}_{63} \mathrm{H}_{98} \mathrm{~N}_{14} \mathrm{O}_{16} 1307.60$ and found 1306.73 (-3.11 ppm).

Acridine- $\mathrm{CH}_{2}-\mathrm{CO}-\mathrm{NH}-\left(\mathrm{CH}_{2}\right)_{2}-\mathrm{O}-\left(\mathrm{CH}_{2}\right)_{2}-\mathrm{O}-\mathrm{CH}_{2}-\mathrm{CO}-\mathrm{NH}-\mathrm{PKIIQSVGI-NH} \mathrm{N}_{2}$ (1e): The general protocol was followed with $0.06 \mathrm{mmol}$ of resin, Fmoc-PEG2-OH, and acridine acetic acid. The crude was purified to give 1 e $(6.2 \mathrm{mg}, 10 \%$ overall yield $)$ as a white lyophilized cotton-like solid. Analytical HPLC (gradient 10-100\% of acetonitrile in 10 min), retention time $=5.51 \mathrm{~min}(98 \%$ analytical purity). HRMS $(\mathrm{ESI},+) \mathrm{m} / \mathrm{z}$ was calculated for $\mathrm{C}_{66} \mathrm{H}_{102} \mathrm{~N}_{14} \mathrm{O}_{15} 1330.76$ and found 1330.77 (1.30 ppm).

Adamantyl- $\mathrm{CH}_{2}-\mathrm{CO}-\mathrm{NH}-\left(\mathrm{CH}_{2}\right)_{2}-\mathrm{O}-\left(\mathrm{CH}_{2}\right)_{2}-\mathrm{O}-\mathrm{CH}_{2}-\mathrm{CO}-\mathrm{NH}-\mathrm{PKIIQSVGI-NH} 2$ (1f): The general protocol for elongation and spacer/hydrophobic residue couplings was performed with $0.06 \mathrm{mmol}$ of resin, Fmoc-PEG2-OH, and adamantyl acetic acid, to give, after purification, 1f (4.7 mg, 7\% overall yield), as a white lyophilized cotton-like solid. Analytical HPLC (gradient $10-100 \%$ of acetonitrile in $10 \mathrm{~min}$ ), retention time $=7.08 \mathrm{~min}(95 \%$ ana- 
lytical purity). HRMS (ESI,+) m/z was calculated for $\mathrm{C}_{62} \mathrm{H}_{107} \mathrm{~N}_{13} \mathrm{O}_{15} 1273.80$ and found 1273.80 (0.07 ppm).

$\mathrm{CH}_{3}-\mathrm{CH}_{2}-\mathrm{CO}-\mathrm{NH}-\left(\mathrm{CH}_{2}\right)_{2}-\mathrm{O}-\left(\mathrm{CH}_{2}\right)_{2}-\mathrm{O}-\mathrm{CH}_{2}-\mathrm{CO}-\mathrm{NH}-\mathrm{PKIIQSVGI}-\mathrm{NH}_{2}(\mathbf{1 g})$ : The general protocol was followed with $0.07 \mathrm{mmol}$ of resin, Fmoc-PEG2-OH, and acetic anhydride. The crude was purified to give $\mathbf{1 g}$, as a white lyophilized cotton-like solid (14.4 mg, $12 \%$ overall yield). Analytical HPLC (gradient $10-100 \%$ of acetonitrile in $10 \mathrm{~min}$ ), retention time $=5.42 \mathrm{~min}(98 \%$ analytical purity). HRMS $(E S I,+) \mathrm{m} / \mathrm{z}$ was calculated for $\mathrm{C}_{52} \mathrm{H}_{93} \mathrm{~N}_{13} \mathrm{O}_{15} 1139.69$ and found 1139.69 (0.69 ppm).

Ph- $\mathrm{CH}_{2}-\mathrm{CO}-\mathrm{NH}-\left(\mathrm{CH}_{2}\right)_{2}-\mathrm{O}-\mathrm{CH}_{2}-\mathrm{CO}-\mathrm{NH}-\mathrm{PKIIQSVGI}-\mathrm{NH}_{2}$ (2a): The general protocols for elongation and spacer/hydrophobic residue couplings were performed with $0.12 \mathrm{mmol}$ of resin, Fmoc-PEG1-OH, and phenylacetic acid. The crude was purified to give $\mathbf{2 a}$, as a white lyophilized cotton-like solid ( $35 \mathrm{mg}, 25 \%$ overall yield). Analytical HPLC (gradient $10-95 \%$ of acetonitrile in $10 \mathrm{~min})$, retention time $=5.59 \mathrm{~min}(87 \%$ analytical purity). HRMS $(E S I,+) \mathrm{m} / \mathrm{z}$ was calculated for $\mathrm{C}_{56} \mathrm{H}_{93} \mathrm{~N}_{13} \mathrm{O}_{14} 1171.70$ and found 1171.70 (1.33 ppm).

(2-(2-oxobenzo[cd]indol-1(2H)-yl)- $\mathrm{CH}_{2}$-CO-NH- $\left(\mathrm{CH}_{2}\right)_{2}$-O- $\mathrm{CH}_{2}$-CO-NH-PKIIQSVGI-NH ${ }_{2}$ (2d): The general protocol was followed with $0.12 \mathrm{mmol}$ of resin, Fmoc-PEG1-OH, and 2-(2-oxobenzo[cd]indol-1 $(2 \mathrm{H})$-yl)acetic acid. The crude was purified to give $2 \mathbf{d}$ (16.5 $\mathrm{mg}$, $11 \%$ overall yield), as a white lyophilized cotton-like solid. Analytical HPLC (gradient $10-95 \%$ of acetonitrile in $10 \mathrm{~min})$, retention time $=5.88 \mathrm{~min}(99 \%$ analytical purity). HRMS $(\mathrm{ESI},+) \mathrm{m} / \mathrm{z}$ was calculated for $\mathrm{C}_{61} \mathrm{H}_{94} \mathrm{~N}_{14} \mathrm{O}_{15} 1262.70$ and found 1262.70 (0.58 ppm).

$\mathrm{Ph}-\mathrm{CH}_{2}-\mathrm{CO}-\mathrm{NH}-\left(\mathrm{CH}_{2}\right)_{2}-\mathrm{CO}-\mathrm{NH}-\mathrm{PKIIQSVGI}-\mathrm{NH}_{2}$ (3a): The general protocol was followed with $0.11 \mathrm{mmol}$ of resin, Fmoc- $\beta$ alanine-OH, and phenylacetic acid. After purification of the crude $3 \mathbf{a}$ (37 mg, 27\% overall yield) was obtained, as a white lyophilized cotton-like solid. Analytical HPLC (gradient $10-100 \%$ of acetonitrile in $10 \mathrm{~min}$ ), retention time $=6.45 \mathrm{~min}$ (97\% analytical purity). HRMS (ESI,+) m/z was calculated for $\mathrm{C}_{55} \mathrm{H}_{91} \mathrm{~N}_{13} \mathrm{O}_{13} 1145.68$ and found 1141.69 (0.29 ppm).

(2-(2-oxobenzo[cd]indol-1(2H)-yl)- $\left(\mathrm{CH}_{2}\right)_{2}-\mathrm{CO}-\mathrm{NH}-\mathrm{CH}_{2}-\mathrm{CO}-\mathrm{NH}-\mathrm{PKIIQSVGI}-\mathrm{NH}_{2}$ (3d): The general protocol was followed with $0.09 \mathrm{mmol}$ of resin, Fmoc- $\beta$ alanine- $\mathrm{OH}$, and 2-(2oxobenzo[cd]indol-1(2H)-yl)acetic acid. The crude was purified to give $\mathbf{3 d}$ as a white lyophilized cotton-like solid (4.6 mg, 4\% overall yield). Analytical HPLC (gradient 10-100\% of acetonitrile in $10 \mathrm{~min})$, retention time $=6.41 \mathrm{~min}(97 \%$ analytical purity). HRMS $(\mathrm{ESI},+)$ $\mathrm{m} / \mathrm{z}$ was calculated for $\mathrm{C}_{60} \mathrm{H}_{92} \mathrm{~N}_{14} \mathrm{O}_{14} 1232.69$ and found 1232.69 (-0.98 ppm).

$\mathrm{Ph}-\mathrm{CH}_{2}-\mathrm{CO}-\mathrm{NH}-\mathrm{PKIIQSVGI}-\mathrm{NH}_{2}$ (4a): The general protocols for elongation and the hydrophobic residue coupling were performed with $0.09 \mathrm{mmol}$ of resin and phenylacetic acid. The crude was purified to give $4 \mathbf{a}$, as a white lyophilized cotton-like solid $(7.16 \mathrm{mg}, 7 \%$ overall yield). Analytical HPLC (gradient $10-100 \%$ of acetonitrile in $10 \mathrm{~min}$ ), retention time $=6.86 \mathrm{~min}\left(92 \%\right.$ analytical purity). HRMS $(\mathrm{ESI},+) \mathrm{m} / \mathrm{z}$ was calculated for $\mathrm{C}_{52} \mathrm{H}_{86} \mathrm{~N}_{12} \mathrm{O}_{12}$ 1070.65 and found 1070.65 (2.37 ppm).

(2-(2-oxobenzo[cd]indol-1(2H)-yl)- $\mathrm{CH}_{2}$-CO-NH-PKIIQSVGI-NH ${ }_{2}$ (4d): The general protocol for elongation and hydrophobic residue coupling were performed with $0.11 \mathrm{mmol}$ of resin and 2-(2-oxobenzo[cd]indol-1(2H)-yl) acetic acid. To give, after purification, $\mathbf{4 d}$ as a white lyophilized cotton-like solid (18 mg, 18\% overall yield). Analytical HPLC (gradient $10-100 \%$ of acetonitrile in $10 \mathrm{~min})$, retention time $=7.38 \mathrm{~min}$ ( $97 \%$ analytical purity). HRMS $(E S I,+) \mathrm{m} / \mathrm{z}$ was calculated for $\mathrm{C}_{57} \mathrm{H}_{87} \mathrm{~N}_{13} \mathrm{O}_{13} 1161.65$ and found 1161.66 (0.55 ppm).

$\mathrm{Ph}-\mathrm{CH}_{2}-\mathrm{NH}-\left(\mathrm{CH}_{2}\right)_{2}-\mathrm{O}-\left(\mathrm{CH}_{2}\right)_{2}-\mathrm{O}-\mathrm{CH}_{2}-\mathrm{CO}-\mathrm{NH}-\mathrm{PKIIQSVGI}-\mathrm{NH}_{2}$ and $\left(\mathrm{Ph}^{-} \mathrm{CH}_{2}\right)_{2} \mathrm{~N}-\left(\mathrm{CH}_{2}\right)_{2}-$ $\mathrm{O}-\left(\mathrm{CH}_{2}\right)_{2}-\mathrm{O}-\mathrm{CH}_{2}-\mathrm{CO}-\mathrm{NH}-\mathrm{PKIIQSVGI}-\mathrm{NH}_{2}$ (7 and 8): Method A: Fmoc-PEG2-peptidil resin (0.03 mmol, RESIN B) was treated with a mixture of piperidine/DBU/DMF (1:1:48 in volume $)$ at room temperature $(1 \times 1 \mathrm{~min}$ and $3 \times 10 \mathrm{~min})$ and washed with DMF/DCM/ $\mathrm{DMF} / \mathrm{DCM}(3 \times 30 \mathrm{~s}$, each solvent $)$ to remove Fmoc group of the spacer. Then, reductive amination protocol was followed using benzaldehyde (3.6 equivalents) and $\mathrm{NaBH}_{3} \mathrm{CN}$ (3.6 equivalents) yielding a mixture of the peptidyl resins 5 and $\mathbf{6}$. After cleavage of the 
mixture, the crude was purified by reverse phase chromatography using semipreparative HPLC (gradient $10-20 \%$ of acetonitrile in $30 \mathrm{~min}$ ).

From the highest mobility fractions, 7 (10.4 mg, 32\% overall yield) was obtained, as a white lyophilized cotton-like solid. Analytical HPLC (gradient $10-100 \%$ of acetonitrile in $10 \mathrm{~min})$, retention time $=5.69 \mathrm{~min}(98 \%$ analytical purity). HRMS $(\mathrm{ESI},+) \mathrm{m} / \mathrm{z}$ was calculated for $\mathrm{C}_{57} \mathrm{H}_{97} \mathrm{~N}_{13} \mathrm{O}_{14} 1188.48$ and found 1187.73 (3.76 ppm).

From the lowest mobility fractions, $3.2 \mathrm{mg}$ (9\% overall yield) of compound $\mathbf{8}$ was obtained, as a white lyophilized cotton-like solid. Analytical HPLC (gradient $10-100 \%$ of acetonitrile in $10 \mathrm{~min})$, retention time $=6.47 \mathrm{~min}(95 \%$ analytical purity). HRMS $(\mathrm{ESI},+) \mathrm{m} / \mathrm{z}$ was calculated for $\mathrm{C}_{64} \mathrm{H}_{103} \mathrm{~N}_{13} \mathrm{O}_{14} 1277.77$ and found 1277.78 (2.95 ppm).

Method B: A similar protocol to that described in method A was followed with 0.073 mmol of Fmoc-PEG2-peptidil resin, which after removal of Fmoc group was reacted with benzaldehyde (10 equivalents) and $\mathrm{NaBH}_{3} \mathrm{CN}$ (10 equivalents), to give, after cleaving and purification by reverse phase on a Biotage Isolera ( $0-100 \%$, acetonitrile), compound 8 (20 $\mathrm{mg}, 21 \%$ overall yield).

(Ph-CH $\mathrm{CH}_{2}(\mathrm{Me})_{2} \mathrm{~N}^{+}-\left(\mathrm{CH}_{2}\right)_{2}-\mathrm{O}-\left(\mathrm{CH}_{2}\right)_{2}-\mathrm{O}-\mathrm{CH}_{2}-\mathrm{CO}-\mathrm{NH}-\mathrm{PKIIQSVGI}-\mathrm{NH}_{2} \mathrm{I}^{-}$and $\left(\mathrm{Ph}^{-} \mathrm{CH}_{2}\right)_{2}$ (Me) $\mathrm{N}^{+}-\left(\mathrm{CH}_{2}\right)_{2}-\mathrm{O}-\left(\mathrm{CH}_{2}\right)_{2}-\mathrm{O}-\mathrm{CH}_{2}-\mathrm{CO}-\mathrm{NH}-\mathrm{PKIIQSVGI}-\mathrm{NH}_{2} \mathrm{I}^{-}$(9 and 10): The mixture of peptidyl resins 5 and $\mathbf{6}(0.073 \mathrm{mmol})$ was quaternized, following the general protocol, by reaction with $\mathrm{MeI}$ in the presence of 2,6-lutidine. After cleavage, the crude was purified by semipreparative HPLC (gradient $10-20 \%$ of acetonitrile in $30 \mathrm{~min}$ ). From the highest mobility fractions, the dimethylated compound 9 was isolated $(22 \mathrm{mg}, 25 \%$ overall yield), as a white lyophilized cotton-like solid. Analytical HPLC (gradient $10-100 \%$ of acetonitrile in $10 \mathrm{~min})$, retention time $=5.70 \mathrm{~min}(99 \%$ analytical purity). HRMS $(\mathrm{ESI},+) \mathrm{m} / \mathrm{z}$ was calculated for $\mathrm{C}_{59} \mathrm{H}_{102} \mathrm{~N}_{13} \mathrm{O}_{14}{ }^{+} 1217.54$ and found 1216.77 (-1.93 ppm).

From the lowest mobility fractions, compound 10 ( $7.9 \mathrm{mg}$, 8\% overall yield) was isolated, as a white lyophilized cotton-like solid. Analytical HPLC (gradient $10-100 \%$ of acetonitrile in $10 \mathrm{~min})$, retention time $=6.33 \mathrm{~min}(98 \%$ analytical purity). HRMS $(\mathrm{ESI},+) \mathrm{m} / \mathrm{z}$ was calculated for $\mathrm{C}_{65} \mathrm{H}_{106} \mathrm{~N}_{13} \mathrm{O}_{14}{ }^{+} 1293.64$ and found 1292.80 (-4.56 ppm).

\subsection{Molecular Modeling and Computer Simulations}

Structural cavities in LiTryR dimer and monomer were calculated using the Computed Atlas of Surface Topography of proteins (CASTp) web server [32] and a probe radius of $1.4 \AA$ A. Molecular dynamics simulations were run in the AMBER force field, as described previously for $L i$ TryR dimer and complexes [22-28]. The molecular graphics program PyMOL (v. 1.8, Schrödinger, 2015) was employed for molecular editing, visualization, and figure preparation.

\subsection{Biological Evaluation \\ 4.4.1. LiTryR Purification}

The recombinant versions of $L i T r y R$ were purified, according to the protocol described by Toro et al. [22]. Briefly, the pRSETA-HIS-LiTryR construct was transformed either alone or in combination with the pET24a-FLAG-LiTryR construct into BL21 (DE3) Rossetta 2 E. coli strain. An overnight culture of E. coli cells grown at $37^{\circ} \mathrm{C}$ in LB medium with suitable antibiotics and vigorous shaking was diluted (1:100) in the same culture medium and allowed to grow in the same conditions until the $\mathrm{OD}_{600}$ reached 0.5. At this point, LiTryR expression was induced with $1 \mathrm{mM}$ isopropyl- $\beta$-D-1-thiogalactopyranoside (Thermo Fisher Scientific, Waltham, MA, USA) for $16 \mathrm{~h}$ at $26^{\circ} \mathrm{C}$. The E. coli cells were harvested by centrifugation at $9000 \times \mathrm{g}$ and $4{ }^{\circ} \mathrm{C}$ for $5 \mathrm{~min}$. The wet pellets were resuspended in a lysis buffer containing $50 \mathrm{mM}$ Tris $\mathrm{pH} 7,300 \mathrm{mM} \mathrm{NaCl}, 25 \mathrm{mM}$ imidazole, $1 \mathrm{mg} / \mathrm{mL}$ lysozyme, and a protease inhibitor cocktail. Following a $30 \mathrm{~min}$ incubation on ice, the cell lysate was disrupted by sonication on ice (50\% pulses, potency 7 ) for $30 \mathrm{~min}$ using a Sonifier Cell Disruptor B15 (Branson, Danbury, CT, USA) and clarified by centrifugation at $50,000 \times g$ and $4{ }^{\circ} \mathrm{C}$ for $1 \mathrm{~h}$. The supernatant containing the soluble protein fraction 
was collected and sonicated again, as previously described for $10 \mathrm{~min}$. The supernatant was filtered using a low protein binding PVDF filter with a pore size of $0.22 \mu \mathrm{m}$ (Merck Millipore, Burlington, MA, USA) and subsequently loaded onto a HisTrap column (GE Healthcare, Chicago, IL, USA) for $16 \mathrm{~h}$ at $4{ }^{\circ} \mathrm{C}$ using a P-1 peristaltic pump (GE Healthcare, Chicago, IL, USA). Once loaded, the HisTrap column was connected to an ÄKTA purifier UPC 10 (GE Healthcare, Chicago, IL, USA) and extensively washed with a 10\% gradient between buffers A (50 mM Tris pH 7 and $300 \mathrm{mM} \mathrm{NaCl})$ and B (50 mM Tris pH 7, $300 \mathrm{mM}$ $\mathrm{NaCl}$, and $500 \mathrm{mM}$ imidazole). Soluble LiTryR was eluted with a $40 \%$ gradient between buffers $\mathrm{A}$ and $\mathrm{B}$. The yellow fractions containing recombinant LiTryR were pooled and subsequently loaded onto a HiPrep 26/10 Desalting column (GE Healthcare, Chicago, IL, USA), previously equilibrated with buffer A. Finally, LiTryR-containing fractions were pooled again and concentrated to $2 \mathrm{mg} / \mathrm{mL}$ using an Amicon ${ }^{\circledR}$ Ultra-15 50K filter (Merck Millipore, Burlington, MA, USA) and an equal volume of glycerol was added before storing at $-20{ }^{\circ} \mathrm{C}$.

\subsubsection{LiTryR Oxidoreductase Activity Assay}

LiTryR oxidoreductase activity was assessed spectrophotometrically using a modified version of the DTNB-coupled assay, described by Hamilton et al. [35]. Briefly, reactions were performed at $26^{\circ} \mathrm{C}$ in $250 \mu \mathrm{L}$ of HEPES buffer $(\mathrm{pH} 7.5,40 \mathrm{mM})$ containing EDTA $(1 \mathrm{mM}), \mathrm{NADP}^{+}(30 \mu \mathrm{M}), \mathrm{DTNB}(25 \mu \mathrm{M}), \mathrm{TS}_{2}(1 \mu \mathrm{M}), \mathrm{NADPH}(150 \mu \mathrm{M})$, glycerol $(0.02 \%)$, DMSO (1.75\%), and recombinant HIS-LiTryR (7 nM). DTNB, glycerol, and DMSO concentrations used in this assay do not have any relevant effect on the kinetics of the LiTryR oxidoreductase reaction. Reactions were started by addition of a mixture ( $50 \mu \mathrm{L} /$ well) of the substrates (NADPH and $\mathrm{TS}_{2}$ ).

LiTryR oxidoreductase activity was monitored at $26^{\circ} \mathrm{C}$ by an increase in absorbance at $412 \mathrm{~nm}$ in an EnSpire Multimode Plate Reader (PerkinElmer, Waltham, MA, USA). In this DTNB-coupled assay, one molecule of $\mathrm{T}(\mathrm{SH})_{2}$ reduces one molecule of DTNB, producing two TNB molecules. The TNB concentration was obtained by multiplying the absorbance values by 100 ( $50 \mu \mathrm{M}$ TNB generates 0.5 arbitrary units of absorbance at $412 \mathrm{~nm})$.

For $\mathrm{IC}_{50}$ determinations, the initial velocities were calculated from the slope of the initial linear part of the reaction curves. The initial velocities of the reaction progress curves in the presence of inhibitor (concentrations ranging from 0.1 to $25 \mu \mathrm{M}$ ) were normalized as a percentage with respect to the initial velocity in the presence of the inhibitor vehicle (DMSO). $\mathrm{IC}_{50}$ values were obtained by fitting these percentages to a nonlinear regression model with GraFit 6 software (Erithacus, Horley, Surrey, U.K.). All the assays were performed in triplicate.

\subsubsection{LiTryR Dimer Quantitation Assay}

The relative amount of the LiTryR dimeric form in the presence of the SMPCs was assessed using an enzyme-linked immunosorbent assay (ELISA), developed in our laboratory [22]. Briefly, HIS-FLAG-tagged LiTryR (400 nM) was incubated in dimerization buffer $(1 \mathrm{~mL}$ of $50 \mathrm{mM}$ Tris $\mathrm{pH} 8.0$ and $300 \mathrm{mM} \mathrm{NaCl})$ for $16 \mathrm{~h}$ at $37^{\circ} \mathrm{C}$ with vigorous shaking and in a humid atmosphere in the presence of the different compounds ranging from 25 to $3.1 \mu \mathrm{M}$. Following a 15 min centrifugation at $18,000 \times g$ and room temperature, the supernatants were added to the $\alpha$-FLAG-coated plates $(200 \mu \mathrm{L} /$ well $)$ and incubated for $30 \mathrm{~min}$ at $37^{\circ} \mathrm{C}$ with vigorous shaking in a humid atmosphere. The plates were washed five times with TTBS buffer ( $2 \mathrm{mM}$ Tris $\mathrm{pH} 7.6,138 \mathrm{mM} \mathrm{NaCl}$, and $0.1 \%$ Tween-20) and incubated with diluted monoclonal $\alpha$-HIS horseradish peroxidase (HRP)-conjugated antibody (200 $\mu \mathrm{L}$ /well, 1:50,000, Abcam, Cambridge, UK) in fatty acid- and essentially globulin-free bovine serum albumin (5\%) prepared in TTBS buffer for $1 \mathrm{~h}$ at room temperature. The plates were washed again five times and the $o$-phenylenediamine dihydrochloride substrate, prepared according to the manufacturer's instructions, was added (100 $\mu \mathrm{L} /$ well $)$. The enzymatic reactions were stopped after $5 \mathrm{~min}$ by addition of $0.5 \mu \mathrm{M} \mathrm{H}_{2} \mathrm{SO}_{4}(100 \mu \mathrm{L} /$ well $)$ 
and the absorbances were measured at $490 \mathrm{~nm}$ in an EnSpire Multimode Plate Reader (PerkinElmer, Waltham, MA, USA).

For $\mathrm{IC}_{50}$ determinations, the absorbance values in the presence of different concentrations of inhibitor were normalized as a percentage with respect to the absorbance value in the presence of DMSO. The $\mathrm{IC}_{50}$ values were obtained by fitting these percentages to a nonlinear regression model with GraFit 6 software (Erithacus, Horley, Surrey, U.K.). The assays were carried out in triplicate and repeated three times.

Author Contributions: Conceptualization, S.V. and M.-J.C.; syntheses, A.R., I.L.-M., S.d.C., and N.Z.; biological evaluations, H.d.L. and J.C.G.-S.; computational modeling studies, A.R. and F.G.; resources, S.V., M.-J.C., A.J.-R., and F.G.; writing-original draft preparation, A.R., S.d.C., H.d.L.; writing-review and editing, S.V., M.-J.C., A.J.-R., and F.G.; supervision, S.V., M.-J.C., A.J.-R., and F.G.; project administration, S.V., M.-J.C., A.J.-R., and F.G; funding acquisition, S.V., M.-J.C., A.J.-R., and F.G. All authors have read and agreed to the published version of the manuscript.

Funding: This research was funded by the Spanish MICINN (Projects PID2019-104070RB-C21 and PID2019-104070RB-C22), by the Spanish Agencia Estatal Consejo Superior de Investigaciones Científicas (CSIC, Projects CSIC-PIE-201980E100 and CSIC-PIE-201980E028), and by the Comunidad de Madrid (PLATESA2-CM ref S-2018/BAA-4370).

Institutional Review Board Statement: Not applicable.

Informed Consent Statement: Not applicable.

Data Availability Statement: Data is contained within the article.

Acknowledgments: The Spanish MEC is acknowledged for a FPU grant to A.R. The University of Alcalá is acknowledged for a FPU grant to J.C.G.-S. and a postdoctoral fellowship to H.d.L.

Conflicts of Interest: The authors declare no conflict of interest.

\section{References}

1. WHO. Leishmaniasis. Available online: https://www.who.int/news-room/fact-sheets/detail/leishmaniasis (accessed on 21 June 2021).

2. Saccoliti, F.; Di Santo, R.; Costi, R. Recent advancement in the search of innovative antiprotozoal agents targeting trypanothione metabolism. ChemMedChem 2020, 15, 1-17. [CrossRef]

3. Burza, S.; Croft, S.L.; Boelaert, M. Leishmaniasis. Lancet 2018, 392, 951-970. [CrossRef]

4. Ready, P.D. Epidemiology of visceral leishmaniasis. Clin. Epidemiol. 2014, 6, 147-154. [CrossRef] [PubMed]

5. Gillespie, P.M.; Beaumier, C.M.; Strych, U.; Hayward, T.; Hotez, P.J.; Bottazzi, M.E. Status of vaccine research and development of vaccines for leishmanisis. Vaccine 2016, 34, 2992-2995. [CrossRef] [PubMed]

6. Chakravarty, J.; Sundar, S. Current and emerging medications for the treatment of leishmaniasis. Exp. Opin. Pharmacother. 2019, 20, 1251-1265. [CrossRef]

7. Alvar, J.; Arana, B.I. Appraisal of leishmaniasis chemotherapy, current status and Pipeline strategies Chapter 1 Leishmaniasis, impact and therapeutic needs. In Drug Discovery for Leishmaniasis; Rivas, L., Gil, C., Eds.; The Royal Society of Chemistry: Cambridge, UK, 2017; pp. 1-23. [CrossRef]

8. Sangshetti, J.N.; Khan, F.A.K.; Kulkarni, A.A.; Arote, R.; Patil, R.H. Antileishmanial drug discovery: Comprehensive review of the last 10 years. Rsc. Adv. 2015, 5, 32376-32415. [CrossRef]

9. Alves, F.; Bilbe, G.; Blesson, S.; Goyal, V.; Monnerat, S.; Mowbray, C.; Ouattara, G.M.; Pécoul, B.; Rijal, S.; Rode, J.; et al. Recent developments of visceral leishmaniasis treatments: Successes, pitfalls and perspectives. Clin. Microbiol. Rev. 2018, 31, e00048-18. [CrossRef] [PubMed]

10. Ponte-Sucre, A.; Gamarro, F.; Dujardin, J.C.; Barrett, M.P.; López-Vélez, R.; García-Hernández, R.; Pountain, A.W.; Mwenechanya, R.; Papadopoulou, B. Drug resistance and treatment failure in leishmaniasis: A 21st century challenge. PLoS Negl. Trop. Dis. 2017, 11, e0006052. [CrossRef]

11. Krauth-Siegel, R.L.; Bauer, H.; Schirmer, R.H. Dithiol proteins as guardians of the intracellular redox milieu in parasites: Old and new drug targets in trypanosomes and malaria-causing plasmodia. Angew. Chem. Int. Ed. 2005, 44, 690-715. [CrossRef]

12. De Rycker, M.; Baragana, B.; Duce, S.L.; Gilbert, I.H. Challenges and recent progress in drug discovery for tropical diseases. Nature 2018, 559, 498-506. [CrossRef]

13. De Gasparo, R.; Brodbeck-Persch, E.; Bryson, S.; Hentzen, N.B.; Kaiser, M.; Pai, E.F.; Krauth-Siegel, R.L.; Diederich, F. Biological evaluation and X-ray co-crystal structures of cyclohexylpyrrolidine ligands for trypanothione reductase, an enzyme from the redox metabolism of Trypanosoma. ChemMedChem 2018, 13, 957-967. [CrossRef] [PubMed] 
14. Fairlamb, A.H.; Blackburn, P.; Ulrich, P.; Chait, B.T.; Cerami, A. Bimane cyclic esters, possible stereologues of trypanothione as antitrypanosomal agents. Bimanes 29. Science 1985, 227, 1485-1487. [CrossRef]

15. Krauth-Siegel, R.L.; Meiering, S.K.; Schmidt, H. The parasitespecific trypanothione metabolism of trypanosoma and leishmania. Biol. Chem. 2003, 384, 539-549. [CrossRef]

16. Frearson, J.A.; Wyatt, P.A.; Gilbert, I.H.; Fairlamb, A.H. Target assessment for antiparasitic drug discovery. Trends Parasitol. 2007, 23, 589-595. [CrossRef]

17. Leroux, A.E.; Krauth-Siegel, R.L. Thiol redox biology of trypanosomatids and potential targets for chemotherapy. Mol. Biochem. Parasitol. 2016, 206, 67-74. [CrossRef] [PubMed]

18. Dumas, C.; Oullette, M.; Tovar, J.; Cunningham, M.L.; Fairlamb, A.H.; Tamar, S.; Olivier, M.; Papadopoulou, B. Disruption of the trypanothione reductase gene of Leishmania decreases its ability to survive oxidative stress in macrophages. EMBO J. 1997, 16, 2590-2598. [CrossRef]

19. Fairlamb, A.H.; Ridley, R.G.; Vial, H.J. Drugs against Parasitic Diseases: RED Methodologies and Issues, Discoveries and Drug Development; TDR/PRD/03.1; WHO: Geneva, Switzerland, 2003; pp. 107-118.

20. Krieger, S.; Schwarz, W.; Ariyanayagam, M.R.; Fairlamb, A.H.; Krauth-Siegel, R.L.; Clayton, C. Trypanosomes lacking trypanothione reductase are avirulent and show increased sensitivity to oxidative stress. Mol. Microbiol. 2000, 35, 542-552. [CrossRef]

21. Wyllie, S.; Cunningham, M.L.; Fairlamb, A.H. Dual action of antimonial drugs on thiol redox metabolism in the human pathogen Leishmania donovani. J. Biol. Chem. 2004, 279, 39925-39932. [CrossRef]

22. Toro, M.A.; Sánchez-Murcia, P.A.; Moreno, D.; Ruiz-Santaquiteria, M.; Alzate, J.F.; Negri, A.; Camarasa, M.J.; Gago, F.; Velázquez, S.; Jiménez-Ruiz, A. Probing the dimerization interface of Leishmania infantum trypanothione reductase with site-directed mutagenesis and short peptides. ChemBioChem 2013, 14, 1212-1217. [CrossRef]

23. Sánchez-Murcia, P.A.; Ruiz-Santaquiteria, M.; Toro, M.A.; De Lucio, H.; Jiménez, M.A.; Gago, F.; Jiménez-Ruiz, A.; Camarasa, M.J.; Velázquez, S. Comparison of hydrocarbon- and lactam-bridged cyclic peptides as dimerization inhibitors of Leishmania infantum trypanothione reductase. RSC Adv. 2015, 5, 55784-55794. [CrossRef]

24. Ruiz-Santaquiteria, M.; De Castro, S.; Toro, M.A.; De Lucio, H.; Gutiérrez, K.J.; Sánchez-Murcia, P.A.; Jiménez, M.A.; Gago, F.; Jiménez-Ruiz, A.; Camarasa, M.J.; et al. Trypanothione reductase inhibition and anti-leishmanial activity of all-hydrocarbon stapled $\alpha$-helical peptides with improved proteolytic stability. Eur. J. Med. Chem. 2018, 149, 238-247. [CrossRef] [PubMed]

25. Ruiz-Santaquiteria, M.; Sánchez-Murcia, P.A.; Toro, M.A.; De Lucio, H.; Gutiérrez, K.J.; De Castro, S.; Carneiro, F.A.C.; Gago, F.; Jiménez-Ruiz, A.; Camarasa, M.J.; et al. First example of peptides targeting the dimer interface of Leishmania infantum trypanothione reductase with potent in vitro antileishmanial activity. Eur. J. Med. Chem. 2017, 135, 49-59. [CrossRef] [PubMed]

26. De Lucio, H.; Gamo, A.M.; Ruiz-Santaquiteria, M.; De Castro, S.; Sánchez-Murcia, P.A.; Toro, M.A.; Gutiérrez, K.J.; Gago, F.; Jiménez-Ruiz, A.; Camarasa, M.J.; et al. Improved proteolytic stability and potent activity against Leishmania infantum trypanothione reductase of $\alpha / \beta$-peptide foldamers conjugated to cell-penetrating peptides. Eur. J. Med. Chem. 2017, 140, 615-623. [CrossRef]

27. Revuelto, A.; Ruiz-Santaquiteria, M.; De Lucio, H.; Gamo, A.; Carriles, A.A.; Gutiérrez, K.J.; Sánchez-Murcia, P.A.; Hermoso, J.A.; Gago, F.; Camarasa, M.J.; et al. Pyrrolopyrimidine vs imidazole-phenyl-thiazole scaffolds in nonpeptidic dimerization inhibitors of Leishmania infantum trypanothione reductase. ACS Infect. Dis. 2019, 5, 873-891. [CrossRef] [PubMed]

28. Revuelto, A.; de Lucio, H.; García-Soriano, J.C.; Sánchez-Murcia, P.A.; Gago, F.; Jiménez-Ruiz, A.; Camarasa, M.J.; Velázquez, S. Efficient dimerization disruption of leishmania infantum trypanothione reductase by triazole-phenyl-thiazoles. J. Med. Chem. 2021, 64, 6137-6160. [CrossRef] [PubMed]

29. Cobb, S.L.; Denny, P.W. Antimicrobial peptides for leishmaniasis. Curr. Opin. Investig. Drugs 2010, 11, 868-875. [CrossRef]

30. Robles-Loaiza, A.A.; Pinos-Tamayo, E.A.; Mendes, B.; Teixeira, C.; Cláudia Alves, C.; Gomes, P.; Almeida, J.R. Peptides to tackle leishmaniasis: Current status and future directions. Int. J. Mol. Sci. 2021, 22, 4400. [CrossRef]

31. Marqus, S.; Pirogova, E.; Piva, T.J. Evaluation of the use of therapeutic peptides for cancer treatment. J. Biomed. Sci. 2017, 24, 21-35. [CrossRef]

32. Tian, W.; Chen, C.; Lei, X.; Zhao, J.; Liang, J. CASTp 3.0: Computed atlas of surface topography of proteins. Nucleic Acids Res. 2018, 46, W363-W367. [CrossRef]

33. Marder, O.; Shvo, Y.; Albericio, F. HCTU and TCTU. New coupling reagents: Development and industrial aspects. Chim. Oggi. 2002, 20, 37-41. [CrossRef]

34. Gellerman, G.; Gaisin, V.; Brider, T. One-pot derivatization of medicinally important 9-aminoacridines by reductive amination and $\mathrm{S}_{\mathrm{N}}$ Ar reaction. Tetrahedrom Lett. 2010, 51, 836-839. [CrossRef]

35. Hamilton, C.J.; Saravanamuthu, A.; Eggleston, I.M.; Fairlamb, A.H. Ellman's-reagent-mediated regeneration of trypanothione in situ: Substrate-economical microplate and time-dependent inhibition assays for trypanothione reductase. Biochem. J. 2003, 369, 529-537. [CrossRef] [PubMed]

36. Lucio, H.; Toro, M.A.; Camarasa, M.J.; Velázquez, S.; Gago, F.; Jiménez-Ruiz, A. Pseudoirreversible slow-binding inhibition of trypanothione reductase by a protein-protein interaction disruptor. Br. J. Pharmacol. 2020, 177, 5163-5176. [CrossRef] [PubMed] 